\title{
Spatial Structure of Eugenia dysenterica Based on Essential Oil Chemovariations and Implications for Conservation and Management of the Genetic Diversity of its Populations
}

\author{
Eliane C. Vilela, ${ }^{a}$ Thays $C$. Carvalho, ${ }^{a}$ Alessandra R. Duarte, ${ }^{a}$ Ronaldo R. Naves, ${ }^{b}$ \\ Suzana C. Santos, ${ }^{a}$ José C. Seraphin ${ }^{c}$ and Pedro H. Ferri*a \\ ${ }^{a}$ Instituto de Química, ${ }^{b}$ Escola de Agronomia e Engenharia de Alimentos and \\ 'Instituto de Matemática e Estatística, Universidade Federal de Goiás, \\ CP 131, 74001-970 Goiânia-GO, Brazil
}

\begin{abstract}
A composição química dos óleos essenciais foi utilizada para estudar a estrutura espacial de oito populações de Eugenia dysenterica do Cerrado central brasileiro. O particionamento da variação utilizando os conjuntos de dados espaciais e ambientais como preditores foi altamente significativo e explicou 7,8 e $8,1 \%$ da variação total dos óleos essenciais, respectivamente. Os resultados sugeriram que o polimorfismo nos óleos essenciais foi determinado mais por fatores genéticos do que ambientais. Além disso, o intercepto do autocorrelograma multivariado de Mantel entre as matrizes de distância dos constituintes químicos e dos locais de coleta sugere que as populações se diferenciam quimicamente a distâncias geográficas superiores a $120 \mathrm{~km}$, contribuindo como indicador alternativo da distância mínima entre amostras necessária para a conservação da diversidade genética das populações.
\end{abstract}

The chemical composition of essential oils was used to study the spatial structure of eight Eugenia dysenterica populations in central Brazilian Cerrado. Variation partitioning using spatial and environmental data sets as predictors was highly significant and explained 7.8 and $8.1 \%$ of oil chemovariations, respectively. Results suggested that essential oil polymorphism was genetically rather than environmentally determined. Furthermore, the intercept of the multivariate Mantel autocorrelogram between the distance matrices of oil constituents and sampling sites suggested that the populations differ chemically whenever geographical distance exceeds $120 \mathrm{~km}$. It stands, therefore, as an alternative indicator of the minimal distance between samples required for conserving the genetic diversity of populations.

Keywords: Eugenia dysenterica, essential oil, variation partitioning, spatial pattern, spatial autocorrelation

\section{Introduction}

The Cerrado Biome spans about a quarter of the Brazilian territory and is characterized by the phytophysiognomic gradient from grassland to forest formations. ${ }^{1}$ Despite Cerrado status as a biodiversity hotspot which houses over 11,000 species of native plants, including 4,400 endemic species, only about $2.2 \%$ of its area enjoys legal protection. ${ }^{2}$ Central Brazilian Cerrado was severely fragmented and degraded by deforestation in the early 1950s, a process accelerated in the 1970 s with the expansion of the agricultural frontier. ${ }^{3}$ An estimation by remote sensing shows that about $47.8 \%$ of Cerrado original vegetation had

*e-mail: pedro@quimica.ufg.br been cleared by 2008 mainly due to cultivated pastures and agricultural crops. ${ }^{4}$ After the Atlantic Forest, Cerrado is the Brazilian Biome that has suffered the greatest anthropogenic impacts, and has been classified among the most threatened biomes in the world. ${ }^{5}$ Thus, strategies to manage, conserve and domesticate wild species are required for the sustainable exploitation of this region.

Among the many tree species found in the Cerrado Biome, Eugenia dysenterica DC. (Myrtaceae), or "cagaiteira" tree, is unique because of its wide range of uses by local human populations. ${ }^{6}$ Its fruits are appreciated for their taste and are consumed in natura or processed to produce different kinds of sweet, jelly, ice cream, liqueur and wine. ${ }^{7}$ A nontoxic peptide from pulp fruits shows in vivo laxative activity which could be used to develop new medications for chronic 
constipation and irritable bowel syndrome treatments. ${ }^{8}$ Commercial frozen pulps exhibit high $\alpha$-glucosidase and $\alpha$-amylase inhibitory activities and represent a potential tool for treating diabetes. ${ }^{9}$ In addition, leaf extracts reveal potential in vitro activities against rotavirus and systemic fungi, which confirms its ethnopharmacological use for treating diarrhoea and dysentery. ${ }^{10}$

E. dysenterica is a perennial species with a long life cycle, and is mainly pollinated by bees and primate (including human) seed dispersal. ${ }^{11}$ These biological and ecological factors often lead to greater genetic variability among populations, including a specific spatial pattern. ${ }^{12}$ In fact, E. dysenterica populations located in Southeast Goiás State have been the object of various genetic studies based on morphological and isozymatic descriptors, ${ }^{13-15}$ as well as on DNA markers such as simple sequence repeats (SSR) and random amplification of polymorphic DNA (RAPD). ${ }^{16,17}$ All of these descriptors showed a similar genetic profile for populations located at around $120 \mathrm{~km}$. This profile decreases with increasing distance, so that populations located more than $190-200 \mathrm{~km}$ away become genetically different as far as these descriptors are concerned. ${ }^{14,16}$ According to this finding, it would be possible to decide which groups of local populations should be given priority in sampling or preserving,${ }^{18}$ as the distribution of genetic variation in the geographical space is an essential factor for the conservation and management of wild populations. ${ }^{19}$

It has been recently suggested that the chemical variation of essential oils from $E$. dysenterica leaves seems to point towards a strong genetic influence on oil chemical composition (chemotypes), despite another recent finding which revealed that chemical variation also resulted in a response to selective pressures under different environmental conditions (ecotypes) for $E$. dysenterica. ${ }^{20}$ These facts suggest that chemical polymorphism in essential oils can be used as an additional criterion in strategies for sample selection and conservation.

Therefore, the chemical variability in essential oils from eight $E$. dysenterica populations located in Southeast Goiás State was performed by gas chromatography coupled with mass spectrometry (GC-MS). Matrices containing the chemical information of the essential oils, geographical coordinates of sampling sites and the physicochemical analysis of soil and foliar nutrients were submitted to chemometric techniques, including a spatial analysis, which enabled the detection of chemical variability patterns in the samples along the environmental and spatial gradient of the populations. Measuring the degree of chemical differentiation among populations and the associated spatial pattern of such chemical divergence may help to develop a new, additional criterion based on chemical profile for the conservation and management of E. dysenterica in the Cerrado region.

\section{Results and Discussion}

In this study, 121 essential oils were extracted from E. dysenterica trees originated from eight populations in Southeast Goiás State. A list of the populations investigated, as well as their provenance, is shown in the Supplementary Information (SI) section (Table S1, Figure S1). The main soil features that showed the highest variations among the sampled original populations were clay, silt, $\mathrm{Al}^{3+}$, potential acidity $\left(\mathrm{H}^{2} \mathrm{Al}^{3+}\right)$, organic matter, macronutrients $\left(\mathrm{K}^{+}\right.$, $\left.\mathrm{Ca}^{2+}, \mathrm{Mg}^{2+}\right)$ and micronutrients $\left(\mathrm{Zn}^{2+}, \mathrm{Mn}^{2+}\right)$, in addition to leaf nutrients $\left(\mathrm{Fe}^{3+}, \mathrm{Zn}^{2+}, \mathrm{Mn}^{2+}\right) \cdot{ }^{13} \mathrm{~A}$ total of 49 chemical constituents (Table S2), mainly sesquiterpenes (30), were measured in each essential oil.

Essential oils revealed a predominance of sesquiterpenes (range of $61.2-80.1 \%$ ), particularly of sesquiterpene hydrocarbons (47.6-68.5\%). Oxygenated sesquiterpenes only showed the lowest values in Campo Alegre de Goiás (4), Cristalina (5) and Senador Canedo (7) (2.29-5.23\%). With the exception of the population from Três Ranchos (3), which showed the lowest levels of monoterpene hydrocarbons (7.81\%), all other samples showed moderate amounts of monoterpenes (12.8-29.1\%).

The most abundant constituent throughout the populations analyzed was (E)-caryophyllene (7.1531.9\%, average value of $18.5 \%$ ), even though it showed the lowest value in specimens from Goiânia $(8)$. $\alpha$-Copaene showed a high percentage $(6.87-12.85 \% ; 8.34 \%)$, except in the populations from Senador Canedo (3.66\%) and Goiânia (5.34\%). Despite the high amounts of $\alpha$-humulene $(7.02-12.7 \%, 9.90 \%)$ and $\delta$-cadinene $(5.0512 .2 \%, 8.85 \%)$, these constituents did not reveal any significant differences among populations. These results are in agreement with previous studies, ${ }^{20}$ although they differ regarding minor constituents. High contents of $(E)$-caryophyllene, which are known to prevent herbivory, ${ }^{21}$ suggest that this essential oil may provide $E$. dysenterica with selective advantages over native species in terms of habitat adaptation against herbivores.

Canonical redundancy analysis (RDA) showed a high correlation between environmental variables (soil and foliar nutrients) and essential oil chemovariations. A significance test with an unrestricted Monte Carlo permutation (999 permutations) found Fischer's $F$-ratio for the first canonical axis $(F$-value $=10.880 ; p=0.002)$ and for all canonical axes $(F=3.090 ; p=0.002)$, giving signs that patterns did not arise by chance. ${ }^{22}$ 
According to the triplot shown in Figure 1, RDA axis 1 clearly correlated to foliar micronutrients $\left(\mathrm{Mn}^{2+}\right.$, $\mathrm{Zn}^{2+}$ ) in samples from Catalão-1 (1), Catalão-2 (2), Três Ranchos (3) and Luziânia (6), whereas an increase in the value of RDA axis 2 is mainly associated with an increase in foliar and soil macronutrients $\left(\mathrm{Ca}^{2+}, \mathrm{Mg}^{2+}, \mathrm{Fe}^{3+}\right)$ from Goiânia (8) and Senador Canedo (7) samples, which reveal high amounts of $\gamma$-cadinene $(7.77-10.7 \%$; 9.80\%). In addition, the decrease in values of RDA axes 1 and 2 is also highly linked to an increment in silt texture and organic matter of soils in Campo Alegre de Goiás (4) and Cristalina (5), whose samples showed the highest (E)-caryophyllene content (20.9-31.9\%; 25.8\%).

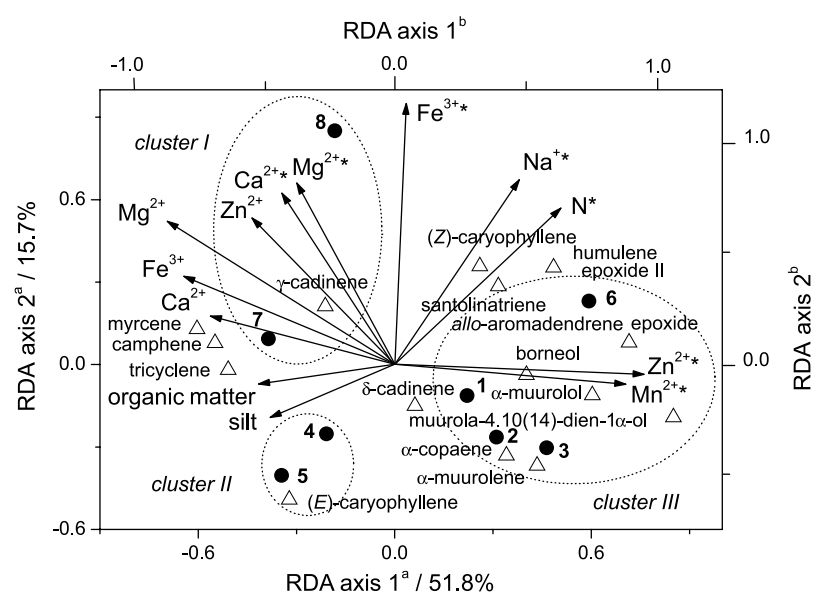

Figure 1. Triplot of the first two RDA axes showing the distribution of E. dysenterica populations $(\bullet ; \mathbf{1 - 8})$. Soil and foliar $(*)$ nutrient parameters were treated as environmental variables and are represented by long arrows from the origin. Oil constituents are represented by triangles instead of arrows. Fitted variables (oils) whose values were $<20 \%$ and environmental variable correlation $<0.40$ are not shown.

A similar hierarchical structure emerges when it is considered the oil constituents grouped together according to carbon skeletons (Table S3 and Figure S2).

Canonical discriminant analysis (CDA) on chemical data confirmed an a priori clustering tendency in the first RDA factorial plane (Table S4 and Figure S3). An axial representation of CDA results discriminated the three groups based only on the contents of $\alpha$-muurolol, $\gamma$-cadinene, $(E)$-caryophyllene and foliar nutrients $\mathrm{Ca}^{2+}$ and $\mathrm{Mn}^{2+}$ as predictor variables. The fitted model showed a high canonical correlation $(R=0.970)$ and a significant Wilks' lambda $(\Lambda=0.023 ; p<0.0001)$, which accounts for a multivariate measure of group differences over predictor variables. The first discriminant function distinguished clusters I and II due to high positive and negative scores of leaf $\mathrm{Ca}^{2+}$ and $(E)$-caryophyllene, respectively, whereas cluster III was separated according to high negative scores of $\alpha$-muurolol and $\mathrm{Mn}^{2+}$ from leaves. It was also possible to make an accurate prediction of $98 \%$ well-classification in the original clusters via the cross-validation approach. This shows that the entire group contributes to discrimination, not only individual plants. The only predicted mismatched classification referred to three samples from cluster III (Luziânia population, 6) which had been classified as belonging to cluster II. Such misclassification might have been caused by a higher level of $(E)$-caryophyllene in the samples, which is characteristic of cluster I. Percentages of oil constituents (or of the constituents that were rearranged according to carbon skeletons) in clustered samples are shown in the SI section (Tables S5 and S6).

For the study of spatial chemical structure, the matrices of Euclidean distances from geographical coordinates and essential oil data sets (chemical constituents or oil constituents rearranged according to carbon skeletons) were submitted to a general linear Mantel test, a randomization technique used to determine associations between distance matrices. ${ }^{23}$ The results showed a significant correlation (Mantel's correlation; $r=0.132, p=0.001$ and $r=0.060$, $p=0.009$, respectively), suggesting that spatial distribution in both oil data sets are not random. These results were confirmed by the variation partitioning performed by partial RDAs on response chemical matrices. ${ }^{24}$ RDAs on oil constituent data set (Table 1) showed that the variation explained only by environmental factors $([\mathrm{A}]=8.1 \%)$ is similar for the pure spatial influence $([\mathrm{C}]=7.8 \%)$, whereas only $0.2 \%$ of variation in essential oils was explained by a environmental-spatial joint effect ([B]). In contrast, the high unexplained variation in oil constituent data (see residuals, $[D]=84 \%)$ suggested that essential oil chemovariations should be mainly determined by genetic factors. ${ }^{25}$

A Monte Carlo permutation test of trace statistics (sum of all canonical eigenvalues) and under the first eigenvalue confirmed the significance of the canonical relationship between chemical matrices and spatial variables $(p<0.001)$. Similar results of variation partitioning were obtained for oil constituents rearranged according to carbon skeletons (data not shown). A Venn diagram showing the variation partitioning is shown in Figure S4.

Even though the Mantel test and the partial RDAs were able to detect (and quantify) the spatial influence, they revealed nothing about the kind of relationship that exists between chemicals and spatial data sets. Thus, the multivariate Mantel correlograms (Figure 2) were obtained for the two chemical data sets with the use of spatial analyses. ${ }^{26}$

The profile of Mantel correlograms showed a decrease in chemical similarity as geographical distances increased, regardless of the essential oil data type. This pattern is similar to those obtained via an isolation-by-distance 
Table 1. Summary of the variation partitioning of E. dysenterica oil constituents using partial RDAs, with environmental and spatial data as predictors

\begin{tabular}{|c|c|c|c|c|c|}
\hline $\begin{array}{l}\text { Effect and main variables } \\
\text { (covariable) }\end{array}$ & Variation fraction & $\begin{array}{l}\text { Explained variation } \\
\left(\operatorname{sum} \lambda^{\mathrm{a}} / \%\right)\end{array}$ & $\begin{array}{c}P^{\mathrm{b}} \\
(\operatorname{sum} \lambda) \\
\end{array}$ & $\begin{array}{c}\text { Explained variation } \\
\left(\lambda_{1}{ }^{c} / \%\right) \\
\end{array}$ & $\begin{array}{c}P \\
\left(\lambda_{1}\right)\end{array}$ \\
\hline \multicolumn{6}{|l|}{ Total effect } \\
\hline Environmental, spatial & {$[\mathrm{A}+\mathrm{B}+\mathrm{C}]$} & 16.1 & 0.001 & 8.3 & 0.001 \\
\hline \multicolumn{6}{|l|}{ Partial effects } \\
\hline Environmental & {$[\mathrm{A}+\mathrm{B}]$} & 8.3 & 0.001 & 3.8 & 0.001 \\
\hline Environmental (spatial) & {$[\mathrm{A}]$} & 8.1 & 0.001 & 4.4 & 0.001 \\
\hline Spatial & {$[\mathrm{B}+\mathrm{C}]$} & 8.0 & 0.001 & 6.0 & 0.001 \\
\hline Spatial (environmental) & {$[\mathrm{C}]$} & 7.8 & 0.001 & 6.5 & 0.001 \\
\hline \multicolumn{6}{|l|}{ Joint effect } \\
\hline Environmental, spatial & {$[\mathrm{B}]$} & 0.2 & & & \\
\hline Residuals & [D] & 84.0 & & & \\
\hline
\end{tabular}

${ }^{a}$ Sum of canonical eigenvalues $(\lambda)$ divided by total inertia (1.0) $\times 100$; brobability on Monte Carlo test ( 999 permutations); cfirst autovalue. The spatial data consist of significant monomials $\left(x^{2}, x^{2} y^{3}\right)$ of third-order polynomial trend surface originated from the first two PCA axes of UTM geographical coordinates (northing, easting) and altitude of the sampling sites.
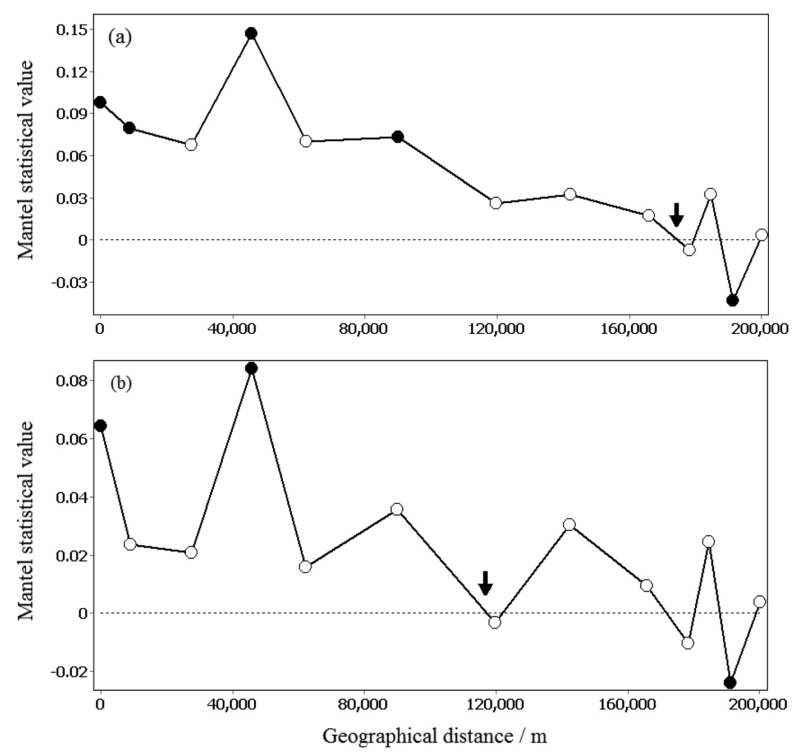

Figure 2. Spatial structure of E. dysenterica populations based on multivariate Mantel correlograms of RDA axis 1 scores for (a) essential oil constituents and (b) oil constituents rearranged according to carbon skeletons. Black circles represent significant $(p<0.05)$ Mantel statistical values (999 permutations). Dashed lines refer to an expected correlation in the absence of spatial autocorrelation and small arrows refer to $x$-intercept at $175 \mathrm{~km}$ (a) and $117 \mathrm{~km}(\mathrm{~b})$.

model, ${ }^{27}$ which confirms that the spatial distribution of essential oil data sets did not arise by chance. The $x$-intercept in the Mantel correlograms (175 and $117 \mathrm{~km}$; Figures $2 \mathrm{a}$ and $2 \mathrm{~b}$, respectively) shows that only populations located at a shorter distance have more chemical similarities in their essential oils than is expected by chance. Below this value, populations are regarded as a homogeneous chemical group and consequently as a chemical operational unit, similar to genetic operational units for the purposes of conserving and managing populations. ${ }^{28}$ This suggests that populations of the minimum distance of $120 \mathrm{~km}$ (carbon skeleton data set) may be considered different as regards essential oil chemovariations, which seem to reflect the genetic variability among the sampled populations.

A few differences were observed between the clusters established by RDA/CDA analyses and the results from spatial statistics. Populations 1-3 and from Luziânia (6) (cluster III) exceed $180 \mathrm{~km}$ between them, which suggests two distinct chemical units, even though they were clustered by RDA/CDA. However, samples from Cristalina (5) and Campo Alegre de Goiás (4) move away from Luziânia and populations 1-3 approximately $130 \mathrm{~km}$, respectively, thus justifying the clustering of their populations (cluster II). This shows that populations located east of Corumbá River are more complex for conservational purposes, a finding in accordance with genetic markers. ${ }^{18}$

In fact, the pattern for E. dysenterica essential oils is in agreement with the evolutionary isolationbydistance model observed for morphological and isozymatic descriptors, ${ }^{13-15}$ as well as for SSR and RAPD genetic markers. ${ }^{16,17}$ In previous studies, the $x$-intercept was located at around $120 \mathrm{~km}$, a finding which suggests that at least the populations to the east and west of the Corumbá River basin should be considered different conservation units and that at least one population from each group should be conserved. This similarity between the two chemical data sets with genetic markers is consistent with the findings of other studies which used terpenoids and isozymes, RAPD, amplified fragment length polymorphism (AFLP), SSR and inter-simple sequence repeat (ISSR) molecular markers. ${ }^{29}$

Unlike the spatial pattern found in Myrciaria cauliflora (Mart.) O. Berg., Myrtaceae) essential oils, ${ }^{25}$ which occurred at a local scale and thus suggested distinct ecotypes, the chemical differentiation among E. dysenterica samples could be explained by isolation due to geographical 
distance, as a result of low-level gene flow among populations. ${ }^{15-18}$ However, this fact should be carefully applied since an extrinsic barrier to gene flow has not always proved necessary for adaptive divergence emerging from isolation in novel habitats and causing speciation. ${ }^{30}$ Terpenes, especially the ones that take part in defense and host recognition mechanisms between a plant (plant interactions) and its herbivores, may play an important role in explaining the observed geographical distribution of species. ${ }^{31}$

Regardless of the underlying process operating in E. dysenterica, essential oil chemovariations may be used as an additional tool to establish in situ conservation areas or sampling areas for ex situ conservation, which bring together the concepts of representativeness and minimum viable population for conservation and management strategies. $^{32}$

\section{Conclusions}

Essential oil analyses of eight $E$. dysenterica populations found in central Brazilian Cerrado revealed high chemical polymorphism, which was mainly related to genetic influences. Furthermore, the multivariate analyses, including those pertaining to spatial patterns, support the use of essential oils as an additional tool to establish chemical units for the management of this species.

\section{Experimental}

\section{Essential oil extraction}

E. dysenterica samples were collected in July 2010 from 121 trees originated from eight populations in Southeast Goiás State, Brazil. To assess essential oils, leaves were dried at room temperature for seven days at $30{ }^{\circ} \mathrm{C}$ until constant weight. After powdering, the dried phytomass (50-100 g) of each sample was submitted to hydrodistillation $(2 \mathrm{~h})$ using a modified Clevenger-type apparatus. At the end of each distillation, the oils were collected and dried with anhydrous $\mathrm{Na}_{2} \mathrm{SO}_{4}$, then transferred to glass flasks where they were kept at a temperature of $-18{ }^{\circ} \mathrm{C}$. Oil yields (\%) were based on the dried weight of plant samples.

\section{Soil and leaf parameters}

Soil parameters of sampling sites $\left(\mathrm{P}, \mathrm{K}^{+}, \mathrm{Ca}^{2+}, \mathrm{Mg}^{2+}\right.$, $\mathrm{Al}^{3+}, \mathrm{Zn}^{2+}, \mathrm{Cu}^{2+}, \mathrm{Fe}^{3+}, \mathrm{Mn}^{2+}, \mathrm{pH}$, organic matter, cationic exchange capacity (CEC), potential acidity $\left(\mathrm{H}+\mathrm{Al}^{3+}\right)$ and soil textures) as well as representative leaf nutrients of each population $\left(\mathrm{N}, \mathrm{P}, \mathrm{S}, \mathrm{K}^{+}, \mathrm{Na}^{+}, \mathrm{Ca}^{2+}, \mathrm{Mg}^{2+}, \mathrm{Zn}^{2+}, \mathrm{Cu}^{2+}\right.$,
$\mathrm{Fe}^{3+}$ and $\mathrm{Mn}^{2+}$ ) previously reported by Telles et al. ${ }^{13}$ were ordered in an environmental data matrix with 27 variables for each sampling site. Organic matter and soil textures were submitted to angular transformation, whereas the other variables were $\log (x+1)$-transformed.

\section{Essential oil analyses}

Oil sample analyses were performed on a GCMS Shimadzu QP5050A instrument under the following conditions: (i) a CBP-5 (Shimadzu) fused silica capillary column $(30 \mathrm{~m} \times 0.25 \mathrm{~mm}$ i.d., $0.25 \mu \mathrm{m}$ film thickness) connected to a quadrupole detector operating in the EI mode at $70 \mathrm{eV}$ with a scan mass range of $40400 \mathrm{~m} / \mathrm{z}$ at a sampling rate of $1.0 \mathrm{scan} \mathrm{s}^{-1}$; (ii) $\mathrm{He}$ as carrier gas

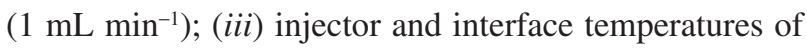
220 and $240{ }^{\circ} \mathrm{C}$, respectively, with a split ratio of 1:20. The injection volume was $0.4 \mu \mathrm{L}$ ( $20 \%$ in hexane) and the oven temperature was raised from 60 to $246^{\circ} \mathrm{C}$ with an increase of $3{ }^{\circ} \mathrm{C} \mathrm{min}{ }^{-1}$, then of $10{ }^{\circ} \mathrm{C} \mathrm{min}^{-1}$ to $270{ }^{\circ} \mathrm{C}$, holding the final temperature for $5 \mathrm{~min}$.

Essential oil constituents were identified by comparing their mass spectra with those recorded by the National Institute of Standards and Technology, ${ }^{33}$ and by comparing mass spectra and calculated linear retention indices (RI) with values found in the literature. ${ }^{34}$ Retention indices were obtained by co-injection with a mixture of linear hydrocarbons, $\mathrm{C}_{8}-\mathrm{C}_{32}$ (Sigma, USA), and by Dool and Kratz's equation. ${ }^{35}$ Representative total ion chromatograms (TIC) of essential oil populations are shown in Figures S5 to S12.

\section{Statistical analyses}

Canonical redundancy analysis (RDA) was applied to describe the patterns of the only explained variation of interrelationships between essential oil constituents $(121 \times 49=5,929)$ or oil constituents rearranged according to carbon skeletons $(121 \times 14=1,694)$, in addition to the interspecific variations as a function of soil and leaf parameters $(121 \times 27=3,267)$, treated as environmental variables..$^{22}$ An unrestricted Monte-Carlo permutation test (999 permutations) was used to test the eigenvalue significance of the first canonical axis as well as the sum (trace) of all canonical axes.

Discriminant analyses via SAS CANDISC and SAS DISCRIM procedures were used to distinguish samples and the clustering tendency in the first two RDA axes on the basis of essential oil composition. ${ }^{36}$ The predictive ability of canonical discriminant function was assessed by a cross-validation approach as implemented in SAS. 
Partial RDA produced constrained ordinations while controlling the effect of a number of significant predictor variables. Total variation partitioning of species data between environmental (soil and foliar nutrients) and spatial components was obtained by partial RDA. ${ }^{24}$ Spatial data consisted of two-dimensional UTM geographical coordinates of plant individuals (northing, easting) and altitude, which were summarized by the PCA first two extracted axes (new $x$ and $y$ coordinates). The new consensus $x$ and $y$ coordinates was completed by adding all terms of a third-order trend surface polynomial equation. Significant monomials were selected via the forward selection procedure available in CANOCO for Windows, ${ }^{37}$ with Bonferroni's adjustment and the variance inflation factor acting to decrease error type I and to assess the multicolinearity in the regression.

The variation partitioning yielded four fractions of species data variation: $[\mathrm{A}]$ local species variation, explained by environmental factors regardless of any spatial structure, [B] spatial structure in the species data which is shared by environmental factors, $[\mathrm{C}]$ spatial structure in the species data which is not shared by environmental factors, and [D] unexplained variation by predictor data sets. ${ }^{24}$ In addition, the Mantel test was used to assess the significance of the relationship between the species similarity matrix and the geographical distance matrix..$^{23}$ The Euclidean distance was used to record these similarity matrices. Multivariate Mantel autocorrelograms (999 permutations) were performed in Pattern Analysis, Spatial Statistics and Geographic Exegesis (PASSAGE) software package. ${ }^{38}$

Multiple comparisons were established by univariate analysis of variance (one-way ANOVA) using SAS GLM procedure. All data was checked for homoscedasticity with the use of Hartley's test. Whenever heteroscedasticity was observed, the variable was angular or rank-transformed. In addition, whenever a difference in ANOVA was established, a Tukey's post-hoc test was performed. Results are given as mean values and in some cases are joined by the standard deviation of independent measurements. $p$-Values below 0.05 were regarded as significant.

\section{Supplementary Information}

Supplementary data (Tables S1-S6, Figures S1-S12) are available free of charge at http://jbcs.sbq.org.br as a PDF file.

\section{Acknowledgements}

We are indebted to Conselho Nacional de Desenvolvimento Científico e Tecnológico (CNPq) and
Programa de Apoio ao Desenvolvimento Científico e Tecnológico (PADCT III) for their financial support, as well as to Conselho de Aperfeiçoamento do Ensino Superior (CAPES) and Fundação de Amparo à Pesquisa do Estado de Goiás (FAPEG) for granting fellowships to E. C. V., A. R. D. and T. C. C (PIBIC-UFG/CNPq).

\section{References}

1. Ribeiro, J. F.; Walter, B. M. In Cerrado: Ambiente e Flora; Sano, S. M.; Almeida, S. P., eds.; Embrapa-CPAC: Planaltina, DF, Brasil, 1998.

2. Marris, E.; Nature 2005, 437, 944.

3. Klink, C. A.; Machado, R. B.; Conserv. Biol. 2005, 19, 707.

4. Sano, E. E.; Rosa R.; Brito, J. L. S.; Ferreira, L. G.; Environ. Monit. Assess. 2009, 1, 1; http://www.mma.gov.br/estruturas/219/_ arquivos/texto_indicadoresdesmatamento_2010_219.pdf accessed in May 2012.

5. Myers, N.; Mittermeier, R. A.; Mittermeier, C. G.; Fonseca, G. A. B.; Kent, J.; Nature 2000, 403, 853; Mittermeier, R. A.; Gil, P. R.; Hoffman, M.; Pilgrim, J.; Brooks, T.; Mittermeier, C. G.; Lamoreux, J.; Fonseca, G. A. B.; Hotspots Revisited: Earth's Biologically Richest and Most Endangered Terrestrial Ecoregions; Conservation International: Arlington, VA, USA, 2005.

6. Fonseca, A.; Muniz, I. A. F.; Inf. Agropec. 1992, 16, 12.

7. Almeida, S. P.; Silva, J.; Ribeiro, J. F.; Aproveitamento Alimentar de Espécies Nativas dos Cerrados: Araticum, Barú, Cagaita e Jatobá; EMBRAPA-CPAC: Planaltina, DF, Brasil, 1987; Oliveira, M. E. S.; Pantoja, L.; Duarte, W. F.; Collela, C. F.; Valarelli, L. T.; Schwan, R. F.; Dias, D. R.; Food Res. Int. 2011, 44, 2391.

8. Lima, T. B.; Silva, O. N.; Oliveira, J. T. A.; Vasconcelos, I. M.; Scalabrin, F. B.; Rocha, T. L.; Grossi-de-Sa, M. F.; Silva, L. P.; Guadagnin, R. V.; Quirino, B. F.; Castro, C. F. S.; Leonardecz, E. L.; Franco, O. L.; Peptides 2010, 31, 1426.

9. Gonçalves, A. E. S. S.; Lajolo, F. M.; Genovese, M. I.; J. Agric. Food Chem. 2010, 58, 4666.

10. Costa, T. R.; Fernandes, O. F. L.; Santos, S. C.; Oliveira, C. M. A.; Lião, L. M.; Ferri, P. H.; Paula, J. R.; Ferreira, H. D.; Sales, B. H. N.; Silva, M. R. R.; J. Ethnopharmacol. 2000, 72, 111; Cecílio, A. B.; Faria, D. B.; Oliveira, P. C.; Caldas, S.; Oliveira, D. A.; Sobral, M. E. G.; Duarte, M. G. R.; Moreira, C. P. S.; Silva, C. G.; Almeida, V. L.; J. Ethnopharmacol. 2012, 141, 975.

11. Donadio, L. C.; Martins, A. B. G.; Valente, J. P.; Fruticultura Tropical; Funep: Jaboticabal, SP, Brasil, 1992; Ferreira M. B.; Cunha, L. H. S.; Inf. Agropec. 1980, 6, 27.

12. Loveless, M. D.; Hamrick, J. L.; Annu. Rev. Ecol. Syst. 1984, 15, 65; Proença, C. E. B.; Gibbs, P. E.; New Phytol. 1994, 126, 343. 
13. Telles, M. P. C.; Silva, R. S. M.; Chaves, L. J.; Coelho, A. S. G.; Diniz-Filho, J. A. F.; Pesq. Agropec. Bras. 2001, 36, 1387.

14. Telles, M. P. C.; Diniz-Filho, J. A. F.; Coelho, A. S. G.; Chaves, L. J.; Rev. Bras. Bot. 2001, 24, 145.

15. Trindade, M. G.; Chaves, L. J.; Genet. Mol. Biol. 2005, 28, 407.

16. Zucchi, M. I.; Brondani, R. V.; Pinheiro, J. B.; Coelho, A. S. G.; Chaves, L. J.; Vencovsky, R.; Rev. Bras. Bot. 2003, 26, 449.

17. Zucchi, M. I.; Pinheiro, J. B.; Chaves, L. J.; Coelho, A. S. G.; Couto, M. A.; Morais, L. K.; Vencovsky, R.; Pesq. Agropec. Bras. 2005, 40, 975.

18. Telles, M. P. C.; Coelho, A. S. G.; Chaves, L. J.; Diniz-Filho, J. A. F.; Valva, F. D.; Conserv. Genet. 2003, 4, 68.

19. McCue, K. A.; Buckler, E. S.; Holtsford, T. P.; Conserv. Biol. 1996, 10, 1425 .

20. Duarte, A. R.; Naves, R. R.; Santos, S. C.; Seraphin, J. C.; Ferri, P. H.; J. Braz. Chem. Soc. 2009, 20, 967; Duarte, A. R.; Naves, R. R.; Santos, S. C.; Seraphin, J. C.; Ferri, P. H.; J. Braz. Chem. Soc. 2010, 21, 1459.

21. Love, A.; Naik, D.; Basak, S. K.; Babu, S.; Pathak, N.; Babu, C. R.; Chem. Biodivers. 2009, 6, 2263.

22. Lepš, J.; Šmilauer, P.; Multivariate Analysis of Ecological Data Using CANOCO; Cambridge University Press: Cambridge, UK, 2007.

23. Mantel, N.; Cancer Res.1967, 27, 209; Legendre, P.; Fortin, M.-J.; Vegetation 1989, 80, 107.

24. Borcard, D.; Legendre, P.; Drapeau, P.; Ecology 1992, 73, 1045; Legendre, P.; Legendre, L.; Numerical Ecology, $2^{\text {nd }}$ ed.; Elsevier Science: Amsterdam, 2003; Wagner, H.; Fortin, M.-J.; Ecology 2005, 86, 1975.

25. Duarte, A. R.; Santos, S. C.; Seraphin, J. C.; Ferri, P. H.; J. Braz. Chem. Soc. 2012, 23, 737.

26. Rossi, R. E.; Mulla, D. J.; Journel, A. G.; Franz, E. H.; Ecol. Monogr. 1992, 62, 277.

27. Sokal, R. R.; Wartenberg, D. E.; Genetics 1983, 105, 219; Sokal, R. R.; Jacquez, G. M.; Evolution 1991, 45, 152.

28. Diniz-Filho, J. A. F.; Telles, M. P. C.; Conserv. Biol. 2002, 16 , 924.
29. Nan, P.; Peng, S.; Shi, S.; Ren, H.; Yang, J.; Zhong, Y.; Z. Naturforsch. 2003, 58c, 57; Adams, R. P.; Socorro, M.; Elizondo, G.; Elizondo, M. G.; Slinkman, E.; Biochem. Syst. Ecol. 2006, 34, 205; Trindade, H.; Costa, M. M.; Lima, S. B.; Pedro, L. G.; Figueiredo, A. C.; Barroso, J. G.; Biochem. Syst. Ecol. 2009, 37, 670; Ben El Hadj Ali, I.; Guetat, A.; Boussaid, M.; Ind. Crops Prod. 2012, 40, 277.

30. Orr. M. R.; Smith, T. B.; Tree 1998, 13, 502; Messaoud, C.; Khoudja, M. L.; Boussaid, M.; Genet. Res. Crop Evol. 2006, 53, 407.

31. Roussis, V.; Tsoukatou, M.; Petrakis, P. V.; Skoula, M.; Harborne, J.; Biochem. Syst. Ecol. 2000, 28, 163; Ehlers, B. K.; Thompson, J.; Oecologia 2004, 141, 511.

32. Vencovsky, R.; Crossa, J.; Crop Sci. 2003, 43,1912; Menges, E. S.; Tree 2000a, 15, 51; Menges, E. S.; Ecol. Bull. 2000b, 48,73 .

33. National Institute of Standards and Technology (NIST); PC version of the NIST/EPA/NIH Mass Spectral Database; US Department of Commerce: Gaithersburg, USA, 1998.

34. Adams, R. P.; Identification of Essential Oil Components by Gas Chromatography/Mass Spectrometry, $4^{\text {th }}$ ed.; Allured: Illinois, USA, 2007.

35. Dool, H. V. D.; Kratz, P. D.; J. Chromatogr. 1963, 11, 463.

36. Statistical Analysis System; SAS Institute Inc.: Cary, NC, USA, 1996.

37. Ter Braak, C. J. F.; Šmilauer, P.; CANOCO Reference Manual and CanoDraw for Windows User's Guide: Software for Canonical Community Ordination, version 4.5; Microcomputer Power: New York, NY, USA, 2002.

38. Rosenberg, M. S.; Anderson, C. D.; Methods Ecol. Evol. 2011, 2, 229.

Submitted: June 20, 2012

Published online: September 25, 2012 